\title{
Neurology and international organizations
}

Section Editors

Johan A. Aarli, MD

Oded Abramsky, MD,

PhD, FRCP

Farrah J. Mateen, MD

Correspondence to

Dr. Mateen:

fmateen@jhsph.edu

\section{ABSTRACT}

A growing number of international stakeholders are engaged with neurologic diseases. This article provides a brief overview of important international stakeholders in the practice of neurology, including global disease-specific programs, United Nations agencies, governmental agencies with international influence, nongovernmental organizations, international professional organizations, large private donors, private-public partnerships, commercial interests, armed forces, and universities and colleges. The continued engagement of neurologists is essential for the growing number of international organizations that can and should incorporate neurologic disease into their global agendas. Neurology ${ }^{\circledR}$ 2013;81:392-394

\section{GLOSSARY}

BMGF = Bill \& Melinda Gates Foundation; MSF = Médicins sans Frontières; NGO = nongovernmental organization; PIH = Partners in Health; UNICEF = United Nations Children's Fund; WFN = World Federation of Neurology.

The future of neurology, its practice and patients, includes multiple international stakeholders. Major changes in international health programming and policy have already altered the incidence, prevalence, and severity of neurologic disease. Recent alliances and declarations are set to change the face of neurologic disease. The following is a brief overview of important international stakeholders related to population-based approaches to neurologic disease in multiple settings.

VERTICAL PROGRAMS FOR NEUROLOGIC DISEASE OF AN INTERNATIONAL SCALE Certain neurologic diseases, usually infectious, have become a priority for international organizations and are marked for eradication or elimination. A resolution to eradicate or eliminate a disease requires commitment from multiple donors and global organizational efforts. The Global Polio Eradication Initiative began in 1988, through a resolution of the World Health Assembly. This initiative has so far engaged 200 countries, 20 million yolunteers, and more than $\$ 8$ billion US dollars. The number of cases of paralytic poliomyelitis has decreased by more than $99 \%$ since 1988 , from 1,000 cases daily to a current total of 325 cases in the reporting year of $2011 .{ }^{1}$ Leprosy infects more than 213,000 people globally, with 249,000 new cases reported in 2008. ${ }^{2}$ A major effort to eliminate leprosy includes free multidrug antibacterial treatment. The London Declaration on Neglected Tropical Diseases (January 2012), which includes endorsement by $>20$ companies and agencies, aims to help eliminate leprosy by 2020 . To achieve this vision, it calls upon the international community to provide resources to remove poverty and exposure to neglected tropical diseases through multiple sectors. ${ }^{3}$

UNITED NATIONS AGENCIES The WHO, a member organization of the United Nations, was formed in 1948. A dedicated Program for Neurologic Diseases and Neuroscience in the Department of Mental Health and Substance Abuse exists at the WHO Headquarters in Geneva, employing one full-time neurologist. Several important policy-level documents have been created through partnerships with the WHO, including "Dementia: A Public Health Priority" (2012), "Atlas: Multiple Sclerosis Resources in the World" (2008), and documents from WHO Mental Health Gap Action Program. Other United Nations agencies, including the World Bank, the United Nations High Commissioner for Refugees, and the United Nations Children's Fund (UNICEF), have played intermittent roles in policy matters related to neurologic disease. For example, UNICEF funded expert speakers at the International Congress of Child Neurologists Association in 2009 in Ukraine to ensure the continued use of vaccines against public concerns of immunization safety. The United

From the Department of International Health, The Bloomberg School of Public Health, Johns Hopkins University, Baltimore, MD.

Go to Neurology.org for full disclosures. Funding information and disclosures deemed relevant by the author, if any, are provided at the end of the article. 
Nations high-level meeting on noncommunicable diseases (September 2011) did not prioritize neurologic disease, but emphasized important risk factors, including hypertension and diabetes.

NATIONAL GOVERNMENTAL AGENCIES WITH INTERNATIONAL INFLUENCE National governments and large urban municipalities have a leading role to play in the prevention and care of neurologic disease. Enactment of laws, such as rules for wearing helmets, programs to achieve mass immunization, standards for drug quality and safety, and provision of insurance for health and rehabilitation, can alter the care of people with neurologic disease, especially those of limited income. Specific governmental agencies may also have a role in understanding emerging neurologic diseases that have international consequences. The Centers for Disease Control and Prevention in the United States, for example, has been important in monitoring diseases such as West Nile virus infection, prion diseases, rabies, and the elusive head-nodding syndrome. The United States Agency for International Development and the UK Department for International Development also influence the burden of neurologic disease by provision of aid for diseases such as AIDS, tuberculosis, and malaria.

NONGOVERNMENTAL ORGANIZATIONS Many large nongovernmental organizations (NGOs) provide care for people with neurologic disease in some of the least developed regions globally. However, many NGOs, likely the great majority, including Médicins sans Frontières (MSF; Doctors without Borders) and Partners in Health (PIH), do not currently have a neurologist on staff (personal communication, Nathan Ford, MSF, and Kria Sakakeeny, PIH, September 2012). Many NGOs have specialized programs for internal medicine or mental health professionals to rotate to selected low- or middle-income countries. These NGOs often welcome neurologists but have no dedicated programs to recruit neurologists or develop care for neurologic patients. Other NGOs, like Rotary International's involvement in the Polio Eradication Initiative, have demonstrated that engagement by private citizens can have a major impact. NGOs dedicated entirely to one or more neurologic diseases remain the exception. Examples of these include the World Neurology Foundation, which provides continuing medical education on neurology to physicians in 37 developing countries, and the Indian Head Injury Foundation.

INTERNATIONAL PROFESSIONAL ORGANIZATIONS Each year, an estimated 6,200 physicians graduate from more than 900 neurology training programs worldwide. ${ }^{4}$ This creates a high potential for large collaborations among neurology trainees and community-based and academic neurologists. The World Federation of Neurology (WFN) is an international organization of country-level neurologic societies, formed in 1957. The WFN includes representation from professional societies in 113 countries. Other major groups include the International League Against Epilepsy, European Federation of Neurological Societies, Pan-African Association of Neurological Societies, the Movement Disorders Society, and the International Headache Society. One successful global event for neurologic disease is World Stroke Day, which is held simultaneously in many countries (next October 29, 2013). A major international campaign for headache includes "Lifting the Burden: the Global Campaign Against Headache."

LARGE PRIVATE DONORS AND PRIVATE-PUBLIC PARTNERSHIPS The Bill \& Melinda Gates Foundation (BMGF) has made a major impact in the field of global health. A large donation from the Foundation led to the development of a low-cost vaccine for Japanese encephalitis in Asia. The Meningitis Vaccine Project (MenAfriVac) is a more recent product development partnership among the BMGF, WHO, PATH, the Serum Institute of India, SynCo Bio Partners of Amsterdam, and others, leading to the development of a meningococcal vaccine for less than 50 cents per dose. ${ }^{5}$ This vaccine has been rolled out to more than 19 million people in sub-Saharan Africa's meningitis belt, including in Mali, Niger, and Burkina Faso.

COMMERCIAL INTERESTS An increasing number of companies are performing clinical trials of drugs and devices for neurologic disease in countries outside of traditional markets, including in low- and middleincome countries. The regulation and appropriateness of such studies has come under scrutiny at times. Commercial interests also come from food manufacturers, tobacco companies, and information technology giants.

ARMED FORCES Armed forces personnel have led to the greater understanding of neurologic disease through their involvement in vaccination campaigns; exposure to new pathogens, toxins, and drugs; and provision of care of people with neurologic disease in times of natural disaster, armed conflict, and other emergencies.

UNIVERSITIES AND COLLEGES Universities are playing an important role in developing partnerships that initiate training opportunities, educational exchanges, and major research and infrastructural support to countries where few neurologists exist. European nations, the United States, Australia, and Canada train many international medical graduates. Practical examples of knowledge exchange include 
"teleneurology," shared grand rounds, and invitational meetings. Global health is a major motivating reason for American students to choose medicine as a career. An uncounted number of formal university partnerships exist between institutions around the world. If cultivated by the neurologic community, such partnerships may stimulate and encourage the next generation of students to become neurologists.

DISCUSSION The types of stakeholders for the advancement of care for people with neurologic disease are changing rapidly. Traditional and established organizations, including the WHO and Ministries of Health, are no longer the sole advocates for neurologic care, nor can they be assumed to take the lead without the engagement of other interested parties. The continued engagement of neurologists is essential for the growing number of international organizations that can and should incorporate neurologic disease into their global agendas.

\section{ACKNOWLEDGMENT}

The author thanks Professor Robert Black, MD, MPH, Chair, Department of International Health, The Johns Hopkins University, for comments and suggestions on an earlier draft of this manuscript.

\section{STUDY FUNDING}

Dr. Mateen is supported by a grant from the Canadian Institutes of Health Research, a fellowship of the Canadian Federation of University Women, and the Bloomberg School of Public Sommer Scholars Program.

\section{DISCLOSURE}

Dr. Mateen has consulted for the WHO, Polio Eradication Initiative, Caritas Lebanon, and the United Nations High Commissioner for Refugees. Go to Neurology.org for full disclosures.

\section{REFERENCES}

1. Polio Eradication Initiative. Available at: http://www. polioeradication.org/. Accessed August 19, 2012.

2. World Health Organization. Leprosy elimination. Available at: http://www.who.int/lep/en/. Accessed August 19, 2012.

3. London Declaration on Neglected Tropical Diseases. NTD partner Web site: uniting to combat NTDs. Available at: http://www.unitingtocombatntds.org/downloads/press/ london_declaration_on_ntds.pdf. Accessed August 19, 2012.

4. Bergen DC, Good D. Neurology training programs worldwide: a World Federation of Neurology survey. J Neurol Sci 2006;246:59-64.

5. Bishai DM, Champion C, Steele ME, Thompson L. Product development partnerships hit their stride: lessons from developing a meningitis vaccine for Africa. Health Aff 2011; 30:1058-1064.

\section{This Week's Neurology ${ }^{\circledR}$ Podcast}

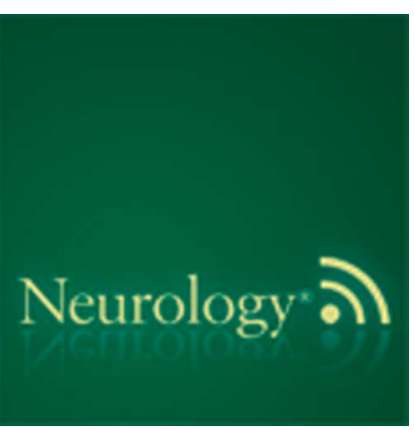

Rasmussen encephalitis treated with natalizumab (See p. 395)

This podcast begins and closes with Dr. Robert Gross, Editor-inChief, briefly discussing highlighted articles from the July 23, 2013, issue of Neurology. In the second segment, Dr. John Mytinger talks with Prof. Heinz Wiendl about his paper on Rasmussen encephalitis treated with natalizumab. Dr. Roy Strowd then reads the e-Pearl of the week about watching for oculomasticatory myorhythmia in Whipple disease. In the next part of the podcast, Dr. Alberto Espay focuses his interview with Dr. Pooja Khatri on intra-arterial therapy being used as standard treatment for acute stroke. Disclosures can be found at www.neurology.org.

At www.neurology.org, click on the "Download Latest Issue" link or "Subscribe Now" to subscribe to the RSS Feed.

CME Opportunity: Listen to this week's Neurology Podcast and earn 0.5 AMA PRA Category 1 CME Credits ${ }^{\mathrm{TM}}$ by answering the multiple-choice questions in the online Podcast quiz. 


\section{Neurology}

\section{Neurology and international organizations \\ Farrah J. Mateen}

Neurology 2013;81;392-394

DOI 10.1212/WNL.0b013e31829c5c73

\section{This information is current as of July 22, 2013}

\section{Updated Information \& Services}

\section{References}

Citations

Subspecialty Collections

\section{Permissions \& Licensing}

\section{Reprints}

including high resolution figures, can be found at: http://n.neurology.org/content/81/4/392.full

This article cites 2 articles, 1 of which you can access for free at: http://n.neurology.org/content/81/4/392.full\#ref-list-1

This article has been cited by 1 HighWire-hosted articles: http://n.neurology.org/content/81/4/392.full\#\#otherarticles

This article, along with others on similar topics, appears in the following collection(s):

\section{All Clinical Neurology}

http://n.neurology.org/cgi/collection/all_clinical_neurology

\section{Health systems}

http://n.neurology.org/cgi/collection/health_systems

Training-international

http://n.neurology.org/cgi/collection/training_international

Information about reproducing this article in parts (figures,tables) or in its entirety can be found online at:

http://www.neurology.org/about/about_the_journal\#permissions

\section{Information about ordering reprints can be found online:}

http://n.neurology.org/subscribers/advertise

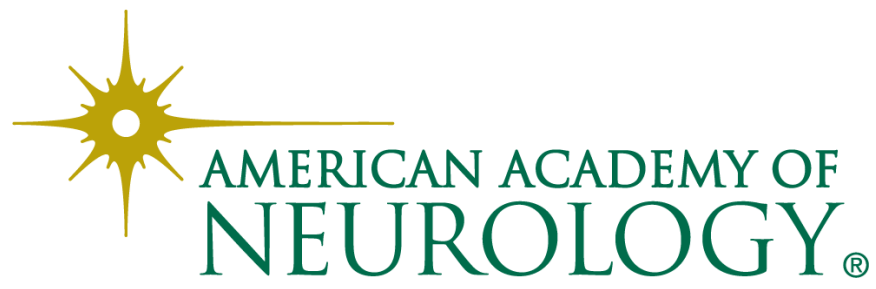

